\title{
及-Amyloid-Related Peptides Inhibit Potassium-Evoked Acetylcholine Release from Rat Hippocampal Slices
}

\author{
Satyabrata Kar, ${ }^{1}$ David Seto,, ${ }^{1,2}$ Pierrette Gaudreau, ${ }^{3}$ and Remi Quirion ${ }^{1,2}$ \\ ${ }^{1}$ Department of Psychiatry, Douglas Hospital Research Center, ${ }^{2}$ Department of Pharmacology and Therapeutics, McGill \\ University, and ${ }^{3}$ Notre Dame Hospital Research Center and Department of Medicine, University of Montreal, Montreal, \\ Québec, Canada H4H $1 R 3$
}

The $4 \mathrm{kDa} \beta$-amyloid $(\mathrm{A} \beta)$ protein, a major component of cerebral and cerebrovascular plaques in Alzheimer's disease (AD), is derived from the proteolytic cleavage of a larger, membranebound precursor, the $A \beta$ precursor protein (APP). Until recently, it was assumed that an aberrant $A D$-specific proteolysis generated $A \beta$ peptides, which subsequently could initiate and/or contribute to the pathological cascade leading to plaque formation and losses of selected neuronal populations, including basal forebrain cholinergic neurons that provide major inputs to the hippocampus and neocortex. However, the recent detection of soluble $A \beta$ fragments in the plasma and CSF of normal individuals, as well as in the conditioned media of cultured brain cells, suggests a role for $A \beta$-related peptides in normal brain functions. Taking into consideration the reported toxic properties of $A \beta$ and the preferential vulnerability of basal forebrain cholinergic neurons in $A D$, we investigated the possible effects of $A \beta$-related peptides on the release of endogenous acetylcholine (ACh) from rat brain slices. $A \beta_{1-28}$, in a concentrationdependent manner $\left(10^{-12}-10^{-8} \mathrm{M}\right)$, potently inhibited $\mathrm{K}^{+}$- evoked ACh release from hippocampal slices. The inhibition of $A C h$ release was fully reversible and was observed using other $A \beta$-related peptides such as $A \beta_{1-42}, A \beta_{1-40}$, and $A \beta_{25-35}$, but not with the scrambled, reverse, or all-D-isomer $A \beta$-peptide sequences, indicating that the effect of $A \beta$ on $A C h$ release is mediated via a stereoselective mechanism. Tetrodotoxin (10 $\mu \mathrm{M})$ failed to alter the effect of $A \beta_{1-28}$ on $A C h$ release, which suggests the lack of involvement of voltage-dependent $\mathrm{Na}^{+}$ channels. Except for the hippocampal formation, the inhibitory effect of $A \beta$ on $K^{+}$-evoked $A C h$ release also was observed in the frontal cortex but not in the striatum. Taken together, our results demonstrate that $A P P$-derived $A \beta$-related peptides can regulate the release of $A C h$ potently by acting on cholinergic terminals. Additionally, the evidence that selected cholinergic neuronal populations are sensitive to $A \beta$ suggests a potential mechanistic link between the deposition of $A \beta$ and the preferential vulnerability of certain cholinergic projections in $A D$.

Key words: acetylcholine; $\beta$-amyloid; hippocampus; neuromodulation; transmitter release; Alzheimer's disease
Excessive extracellular deposition of $\beta$-amyloid $(A \beta)$, a polypeptide of 39-43 amino acids, in brain parenchyma and cerebromeningeal blood vessels is a pathological hallmark of Alzheimer's disease (AD) (Mullan and Crawford, 1993; Cordell, 1994; Selkoe, 1994). This peptide is generated by the proteolytic cleavage of the $\mathrm{A} \beta$ precursor protein (APP), a transmembrane glycoprotein that exists as multiple isoforms resulting from the alternative splicing of a single transcript (Kang et al., 1987; Selkoe, 1993; Nitsch and Growdon, 1994). Several lines of evidence over the last decade have directly or indirectly implicated $A \beta$ deposition as an initiating and/or contributing factor in the pathogenesis of AD (Mullan and Crawford, 1993; Cordell, 1994; Cotman and Pike, 1994; Hardy and Allsop, 1994; Selkoe, 1994; St George-Hyslop, 1994; Games et al., 1995; LaFerla et al., 1995). Because the normal processing of APP precludes intact $A \beta$ formation (i.e., the extracellular domain of APP is clcaved at residue 16 within the $A \beta$ region), it was assumed that assembly/deposition of $A \beta$ protein in AD was caused by abnormal APP maturation (Esch et al., 1990; Sisodia et al., 1990; Cordell, 1994; Selkoe, 1994). However, the

Received Sept. 13, 1995; revised Nov. 1, 1995; accepted Nov. 2, 1995.

This work was supported by the Medical Research Council of Canada. R.Q. is the recipient of "Chercheur Boursier de Mérite Fxceptionel," P.G. is a "Scholar." and D.S. is the recipient of the "Studentship Award" from the Fonds de la Recherche en Santé du Québec

Correspondence should be addressed to Dr. Remi Quirion, Douglas Hospital Research Center, 6875 La Salle Boulevard, Verdun, Québec. Canada H4H IR3.

Copyright 1996 Society for Neuroscience $\quad 0270-6474 / 96 / 161034-07 \$ 05.00 / 0$ recent reports that $A \beta$ peptides are secreted by cultured brain cells and can be detected in human plasma and CSF clearly indicate that $\mathrm{A} \beta$ can be secreted constitutively under normal conditions and, therefore, may have physiological functions (Haass et al., 1992; Seubert et al., 1992; Shoji et al., 1992). At present, neither the mechanisms underlying $A \beta$-mediated degenerative cascade nor the physiological functions of soluble $A \beta$, if any, are clearly established.

Accompanying $A \beta$ deposition, certain brain regions, particularly the basal forebrain neurons that provide major cholinergic inputs to the hippocampus and neocortex, are affected most severely in AD (Price, 1986; Hohmann et al., 1988; Geula and Mesulam, 1994). In parallel with neuronal losses, choline acetyltransferase activity, high-affinity choline uptake, acetylcholinesterase $(\mathrm{AChE})$ activity and, most importantly, the level of acetylcholine (ACh) are decreased significantly in cortical and hippocampal regions of the AD brain (Price, 1986; Hohmann et al., 1988; Wurtman, 1992; Quirion, 1993; Gcula and Mcsulam, 1994). It has been suggested that losses of hippocampal and cortical cholinergic innervation contribute to the progressive memory impairment associated with AD (Hohmann et al., 1988; Cordell, 1994; Geula and Mesulam, 1994; Selkoe, 1994). However, the cause of the rather early decimation of the basal forebrain cholinergic neurons in $\mathrm{AD}$ remains unclear.

Considering the preferential vulnerability of selected cholinergic neurons (Cordell, 1994; Geula and Mesulam, 1994; Selkoe, 
1994) and the neurotoxic potential of $A \beta$ (Yankner et al., 1990; Mattson et al., 1993; Pike et al., 1993; Cotman and Pike, 1994), it is critical to establish whether functional inter-relationships exist between $A \beta$ and these neurons, especially those affected in AD. Recent evidence suggested that the lesioning of basal forebrain cholinergic neurons elevates the ex vivo synthesis of cortical APP (Wallace et al., 1993) and that the activation of specific muscarinic receptor subtypes influences the normal maturation of APP (Buxbaum et al., 1992; Nitsch et al., 1992, Nitsch and Growdon, 1994). Application of $A \beta$ also has been shown to induce the hypofunction of cholinergic neurons, although with delayed efficacy (Abe et al., 1994; Giovannelli et al., 1995). However, it is not known whether $A \beta$-related peptides can affect the functioning of cholinergic neurons. The present study reports that $A \beta$-related peptides can inhibit $\mathrm{ACh}$ release potently, likely by acting on cholinergic terminals of the rat hippocampus and cortex, whereas they are ineffective in the striatum. The finding that selected cholinergic neurons respond to $A \beta$ may provide a functional link between the deposition of $A \beta$ and the preferential vulnerability of certain cholinergic projections in AD.

\section{MATERIALS AND METHODS}

Materials. Adult male Sprague-Dawley rats (275-300 gm; Charles River Laboratories, St. Constant, Ouebec, Canada), maintained under institutional and the Canadian Council for Animal Care guidelines, were used in the study. Human $A \beta$ peptides including $A \beta_{1-42}, A \beta_{1-41}, A \beta_{1-28}$, $\mathrm{A} \beta_{25-\{,}$, and $\mathrm{A} \beta_{4(1)-1}$ (reverse sequence of $\mathrm{A} \beta_{1-40}$ ) were obtained from Bachem (Torrance, $C A$ ). Scrambled $A \beta_{25-35}$ was synthesized and purified in our laboratory, whereas the all-D-isomers of $A \beta_{25-35}$ were a gift from Dr. M. Staufenbiel (Sandoz Plarma, Basel, Switzerland). Peptides were stored lyophilized at $-20^{\circ} \mathrm{C}$ and were dissolved in double distilled water, according to the manufacturer's instructions, immediately before use. Under these conditions, no evidence of oxidation, aggregation, or degradation was reported (Maggio et al., 1992). ACh chloride, physostigmine sulfate, choline kinase (ATP, choline phosphotransferase), AChE type V-S (ACh hydrolase), and tetrodotoxin (TTX) were obtained from Sigma (St. Louis, MO), and ATP and dithiothreitol (DTT) were purchased from Boehringer Mannheim (Laval, Quebec, Canada). Tetraphenylboron and butyronitrile were from Aldrich (Milwaukee, WI); AG 1-X8 Resin was from Bio-Rad (Hercules, CA), and $\left[\gamma_{-}{ }^{32} \mathrm{P}\right] \mathrm{ATP}(2-10 \mathrm{Ci} / \mathrm{mmol})$ was from DuPont NEN (Mississauga, Ontario, Canada). All other chemicals were purchased either from Sigma or from Fisher Scientific (Montreal, Quebec, Canada).

Tissue preparation und superfusion. Rats were killed by decapitation, and the selected brain regions i.e., hippocampus, striatum, or frontal cortex, were dissected out on ice and sliced to $400 \mu \mathrm{m}$ with a McIlwain tissue chopper (Mickle Laboratory Engineering, Gomshall, Surrey, UK). Slices of one hemisphere were transferred to a superfusing chamber (Brandel Instruments, Gaithersburg, MD) and superfused continuously with oxygenated Krebs' buffer [(in mM) $\mathrm{NaCl} 120, \mathrm{KCl} 4.6, \mathrm{CaCl}_{2} 2.4$, $\mathrm{KH}_{2} \mathrm{PO}_{4} 1.2, \mathrm{MgSO}_{4} 1.2, \mathrm{D}$-glucose $9.9, \mathrm{NaHCO}_{3} 25$, adjusted to $\left.\mathrm{pH} 7.4\right]$ at $37^{\circ} \mathrm{C}$ at a flow rate of $0.5 \mathrm{ml} / \mathrm{min}$. The buffer also contained physostigmine $(30 \mu \mathrm{M})$ to prevent degradation of ACh and choline chloride (10 $\mu \mathrm{M})$ to support a constant supply of precursor for the synthesis of ACh. Effluents for the first $45 \mathrm{~min}$ were discarded to establish a stable basal efflux of $\mathrm{ACh}$, and thereafter samples were collected every $20 \mathrm{~min}$. After $1 \mathrm{hr}$ of basal efflux, the tissues were stimulated with high- $\mathrm{K}^{+}$Krebs' buffer ( $25 \mathrm{~mm} \mathrm{KCl}$ with equimolar reduction in $\mathrm{NaCl}$ to conserve isotonicity) in the presence or absence of regular or altered $A \beta$-related peptides. To determine whether the transient exposure to $A \beta$ could modify the subsequent $A C h$ release, some tissue slices after the typical $1 \mathrm{hr}$ stimulation with $\mathrm{A} \beta$ peptides were rinsed with normal Krebs' buffer $(40 \mathrm{~min})$ and then restimulated for an additional $1 \mathrm{hr}$ in the absence of the peptide. At the end of each experiment, tissue slices were removed and protein content was measured (Lowry et al., 1952). The superfusates collected every $20 \mathrm{~min}$ were spun $\left(15,000 \times \mathrm{g}, 5 \mathrm{~min}, 4^{\circ} \mathrm{C}\right)$, and $1.5 \mathrm{ml}$ of the supernatant then was stored at $-70^{\circ} \mathrm{C}$ until further processing.

Radioenzymatic analysis of ACh. Superfusion samples, as described in detail previously (Hanisch et al., 1993), were processed in triplicate for $\mathrm{ACh}$ analysis using a radioenzymatic assay (Goldberg and McCaman, 1973). Briefly, ACh was extracted from the samples by mixing a $400 \mu \mathrm{l}$ aliquot with an cqual volume of tetraphenylboron $(30 \mathrm{~mm})$ in butyronitrile. After centrifugation, $300 \mu$ lof the organic phase was removed and shaken (4 min) with a half-volume of $\mathrm{AgNO}_{3}$ solution $(120 \mathrm{~mm})$. The mixture was spun $\left(15,000 \times g, 4 \mathrm{~min}, 22^{\circ} \mathrm{C}\right)$, and the excess silver present in the aqueous phase was precipitated by the addition of $10 \mu \mathrm{l} \mathrm{of} \mathrm{MgCl}_{2}$ $(1 \mathrm{M})$. Finally, after shaking $(4 \mathrm{~min})$ and spinning $(15,000 \times \mathrm{g}, 4 \mathrm{~min}$, $22^{\circ} \mathrm{C}$ ), a $100 \mu$ l volume of supernatant was removed and lyophilized. The samples then were redissolved in $32 \mu \mathrm{l}$ of a reaction medium containing ATP $(0.8 \mathrm{~mm})$, DTT $(5 \mathrm{~mm}), \mathrm{MgCl}_{2}(12.5 \mathrm{~mm})$, glycylglycine $(25 \mathrm{~mm}, \mathrm{pH}$ 8 ), and choline kinase $(5 \mathrm{mU})$ and incubated at $30^{\circ} \mathrm{C}$ for $25 \mathrm{~min}$ to phosphorylate the choline in the sample. A solution $(10 \mu \mathrm{l})$ containing AChE $(2 \mathrm{U})$ and $\left[\gamma^{32}\right.$ P]ATP $(0.45 \mu \mathrm{Ci})$ then was added to each sample, followed by another incubation of the samples for an additional $25 \mathrm{~min}$ at $30^{\circ} \mathrm{C}$. During the second incubation, $\mathrm{ACh}$ was hydrolyzed and the choline that formed was phosphorylated to $\left[{ }^{32} \mathrm{P}\right]$ phosphorylcholine. The reaction was terminated by the addition of $100 \mu \mathrm{l}$ of $\mathrm{NaOH}(0.05 \mathrm{~mm})$, and the radioactive phosphorylcholine then was separated from the radioactive ATP by ion-exchange chromatography on column of AG 1-X8 Resin. Phosphorylcholine, eluted with $3 \mathrm{ml}$ of $\mathrm{NaOH}(0.05 \mathrm{~mm})$, was mixed with scintillation cocktail, and the radioactivity was measured by liquid scintillation spectrometry. For each experiment, standard amounts of ACh dissolved in Krebs' buffer were processed in parallel to monitor recovery.

Statistical analysis. Evoked transmitter release was expressed as pmol $\mathrm{ACh} \cdot \mathrm{min}^{-1} \cdot \mathrm{mg}$ protein ${ }^{-1}$ and considered to be net transmitter release over the basal efflux. The basal efflux was determined from the superfusate samples collected before, during, and after the $\mathrm{K}$ stimulation, depending on the experimental paradigm. The data were analyzed statistically using one-way ANOVA followed by Fisher's post hoc test, and the level of significance was set at $p<0.05$.

\section{RESULTS \\ Effects of $A \beta$-related peptides on hippocampal ACh release}

Stimulation of $\mathrm{ACh}$ release with $25 \mathrm{~mm} \mathrm{KCl}$ is known to be submaximal and is appropriate to reveal both drug-dependent attenuation and augmentation of transmitter release (Pearce et al., 1991; Hanisch et al., 1993). For example, it is by this method that the existence of presynaptic muscarinic receptors first was proposed (Rodriguez de lores Arnaiz, 1988; Quirion, 1993). To assess whether $A \beta$-related peptides can affect the release of endogenous $\mathrm{ACh}$ acutely, hippocampal slices were superfused in $25 \mathrm{~mm} \mathrm{~K}^{+}$Krebs' buffer in either the absence or the presence of various concentrations of $A \beta_{1-28}$, a derivative that neither forms stable aggregate nor exhibits toxicity (Pike et al., 1993). The results clearly demonstrate that $A \beta_{1-28}$, in a concentration $\left(10^{-12}-10^{-8} \mathrm{M}\right)$-dependent manner, potently inhibited endogenous $\mathrm{ACh}$ release (Fig. 1). The time dependence of the effects of $\mathrm{A} \boldsymbol{\beta}_{1-28}$ revealed that the potent inhibition of $\mathrm{ACh}$ release was apparent during the final $40 \mathrm{~min}$ at $10^{-8} \mathrm{M}$, whereas at lower concentrations (i.e., $10^{-12}-10^{-10} \mathrm{M}$ ), significant decreases in $\Lambda \mathrm{Ch}$ were evident during the final $20 \mathrm{~min}$ of stimulation (Table 1). This likely is related to the relatively slow tissue penetration of $A \beta_{1} 28$. No significant alterations in $\mathrm{K}^{+}$-evoked $\mathrm{ACh}$ release were observed at any time point from the tissue samples treated with $10^{-16}-10^{-14} \mathrm{MA} \beta_{1-28}$ (Fig. 1). The spontaneous release of $\mathrm{ACh}$ from hippocampal slices was not altered significantly by $10^{-8} \mathrm{M}$ $\mathrm{A} \beta_{1-28}$.

To explore further the structure-activity relationship of the inhibitory action of $\mathrm{A} \beta$-related peptides, the effects of $\mathrm{A} \beta_{1-42}, \mathrm{~A} \beta_{1-40}$, and $A \beta_{25-35}$ were evaluated under similar conditions (Fig. 2). All of these $A \beta$-related derivatives induced potent inhibition of $\mathrm{K}^{+}$-evoked $A C h$ release from rat hippocampal slices. The time-dependent response indicates that the selective inhibition of $\mathrm{ACh}$ release by various $A \beta$-related peptides, like $A \beta_{1-28}$, is observed primarily during the later periods of evoked release (Fig. 2). 


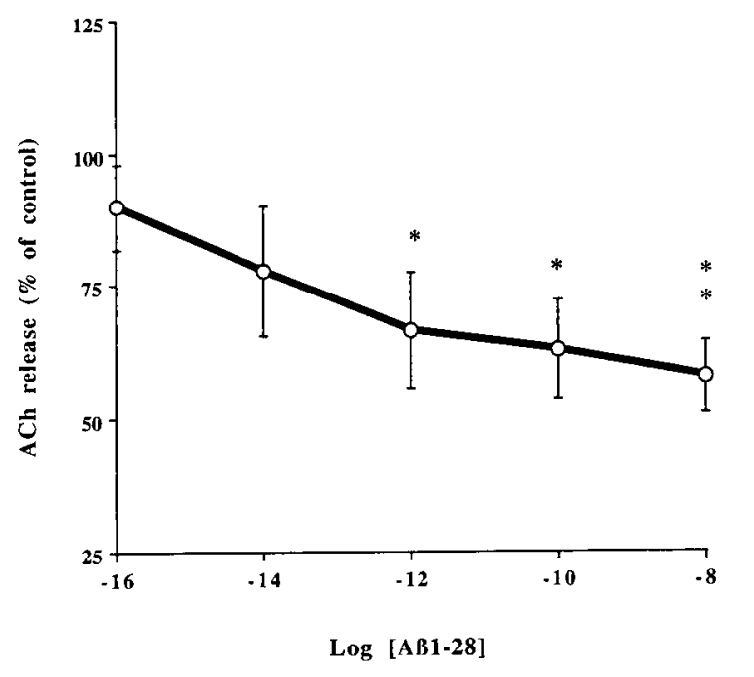

Figure 1. Effects of $\mathrm{A} \beta_{1-28}$ on evoked $\mathrm{ACh}$ release from hippocampal slices. Slices were depolarized with $25 \mathrm{~mm} \mathrm{~K}^{+}$buffer in the presence or absence (control) of various concentrations of $A \beta_{1-2 x}$. Evoked release was inhibited significantly at concentrations ranging from $10^{12}$ to $10^{8} \mathrm{M}$. Results are expressed as mean \pm SEM of three experiments, each performed five times for each concentration of peptide tested. ${ }^{*} p<0.05 ;{ }^{*}{ }^{*} p$ $<0.01$.

\section{Specificity of $A \beta$ effects on $A C h$ release}

A central issue relates to the specificity of the effects of $A \beta$ related peptides. Accordingly, hippocampal slices were superfused with a scrambled $A \beta_{25-35}$ sequence as well as the reverse sequence of $A \beta_{1-40}\left(A \beta_{40-1}\right)$. Unlike the normal derivatives, neither of the altered sequence of $A \beta$ peptides affected the endogenous release of ACh from hippocampal slices (Fig. 3). Using an all-D-isomer $\mathrm{A} \beta_{25-35}$, Frey et al. (1994) suggested recently that in vitro toxic effects of $\mathrm{A} \beta$ were mediated via some unknown mechanisms at the cellular membranes but not via specific "ligand-receptor-like" interactions, because both $A \beta_{25-35}$ and the all-D-isomer demonstrated similar effects. Unlike $A \beta_{25-35}$, the all-D-isomer peptide did not affect evoked release of ACh from hippocampal slices (Fig. 3), which suggests that the inhibition of $\mathrm{ACh}$ release is mediated via a stereospecific interaction. Moreover, preliminary results suggest that $A \beta$ peptides $\left(10^{-12}\right.$ $10^{-8} \mathrm{M}$ ) fail to alter endogenous amino acid release (glutamate, aspartate, and GABA measured by HPLC) in rat hippocampal slices (D. Auld, S. Kar, and R. Quirion, unpublished observations).

\section{Reversal of $\mathbf{A} \boldsymbol{\beta}$-mediated inhibition of $\mathrm{ACh}$ release}

When hippocampal slices were stimulated twice for a period of 1 $\mathrm{hr}$, each preceded by a $40 \mathrm{~min}$ rinse, the magnitude of $\mathrm{ACh}$ release induced by the first and second phases of stimulation was similar. To assess whether the presence of an $A \beta$ peptide during the first phase of stimulation could alter subsequent $\mathrm{ACh}$ release, hippocampal slices were exposed to $\mathrm{A} \beta_{1-28}\left(10^{-8} \mathrm{M}\right)$ during the first stimulation, followed by a washout and a second stimulation. $\mathrm{A} \beta_{1-2 \delta}$ inhibited $\mathrm{ACh}$ release during the first phase of stimulation but did not affect release after its washout (Fig. 4). This result clearly indicates that pre-exposure to $A \beta$ did not modify the subsequent $\mathrm{ACh}$ release pattern, thus excluding acute toxic effects of $A \beta$ for the duration of the experiment.

\section{Effects of TTX on A $\beta$ inhibition of $A C h$ release}

TTX is known to suppress neuronal depolarization and firing caused by fluxes through voltage-sensitive $\mathrm{Na}^{+}$channels (Nara- hashi, 1974). By itself, TTX (10 $\mu \mathrm{M})$ does not alter evoked ACh release in the hippocampal slices (Araujo et al., 1990). Moreover, $\mathrm{A} \beta_{1-28}\left(10^{-8} \mathrm{M}\right)$-mediated inhibition of $\mathrm{ACh}$ release was unaffected in the presence of $10 \mu \mathrm{M}$ TTX (Fig. 5). This indicates that initiation of impulses distal to cholinergic terminals is not required to induce the inhibition of $A C h$ release observed with $A \beta$ peptides.

\section{Regional differences in $\mathbf{A} \boldsymbol{\beta}$ inhibition of $\mathbf{A C h}$ release}

Except for the hippocampal formation, cholinergic terminals are most abundant in cerebral cortex and striatum (Hohmann et al., 1988; Geula and Mesulam, 1994). To investigate the regional specificity of $\mathrm{A} \beta$-mediated inhibition of $\mathrm{ACh}$ release, slices of frontal cortex or striatum were superfused in the presence or absence of $10^{-8}$ м $\mathrm{A} \beta_{1-28}$. Whereas $\mathrm{A} \beta_{1-28}$ did not affect the $\mathrm{K}^{+}$-evoked release of ACh from striatal slices (Fig. $6 A$ ), the responses of cortical $\mathrm{ACh}$ release were found to be decreased significantly (Fig. 6B). As in the hippocampal formation, the inhibition was apparent primarily during the later period of stimulation (Fig. 6B).

\section{DISCUSSION}

The present results clearly indicate that $A \beta$ peptide with a unique potency can inhibit $\mathrm{K}^{+}$-evoked $\mathrm{ACh}$ release from selected regions of the rat brain. The effect of the peptide is as follows: (1) it is concentration-dependent, with significant inhibition observed over a broad range of concentrations (i.e., $10^{-12}-10^{-8} \mathrm{M}$ ); (2) it is highly selective, because scrambled, reverse, or all-D-isomer $A \beta$ peptides did not alter ACh release; and (3) it is region-specificterminals of the hippocampal formation and frontal cortex are sensitive, whereas striatal intrinsic cholinergic neurons are unaffected. Furthermore, because $A \beta$-related peptides with (i.e., $A \beta_{1-42}, A \beta_{1-40}$, and $A \beta_{25-35}$ ) or without (i.e., $A \beta_{1-28}$ ) the hydrophobic 29-35 sequence believed to be essential for toxicity (Pike et al., 1993; Cotman and Pike, 1994) induced similar inhibition of $\mathrm{ACh}$ release, it is unlikely that the observed effect was caused by acute peptide toxicity. The lack of effect of the tissue pre-exposure to $\mathrm{A} \beta_{1-28}$ on subsequent $\mathrm{ACh}$ release also supports this hypothesis.

The synaptic release of ACh is modulated by various agents, including cholinergic drugs themselves (i.e., autoregulation) (Quirion, 1993), other transmitters/modulators such as excitatory amino acids (Cai et al., 1991), and trophic factors such as the insulin-like growth factors (Araujo et al., 1989) and cytokines, in particular, interleukin-2 (Hanisch et al., 1993). However, the concentrations of these agents required to alter $\mathrm{ACh}$ release are usually much greater than for $\mathrm{A} \beta$ derivatives, often in the low micromolar range. For example, oxotremorine, a muscarinic M2receptor antagonist, at $10 \mu \mathrm{M}$ concentration inhibits only $45 \%$ of the croked $\mathrm{ACh}$ rclcasc from rat hippocampal slices (Quirion, 1993). Accordingly, A $\beta$-related peptides are among the most potent, if not the most potent, regulators of brain $\mathrm{ACh}$ release characterized thus far. Of importance, $A \beta$ derivatives likely act on cholinergic nerve terminals to inhibit ACh release, as demonstrated by the insensitivity to TTX. Moreover, the lack of effects of the reverse sequence $\mathrm{A} \beta_{40-1}$, the scrambled $\mathrm{A} \beta_{25-35}$ analog, and the all-D-isomer $\mathrm{A} \beta_{25-35}$ homolog demonstrates further the specificity and stereoselective nature of the observed inhibitory response of $\mathrm{A} \beta$-related peptides on $\mathrm{ACh}$ release. These findings, together with the evidence that APP-like immunoreactivity is present in neurons and fibers intrinsic to the hippocampal and cortical regions (Beeson et al., 1994; Ouimet et al., 1994), which are known to make contact with terminals originating from basal 
Table 1. Effects of $A \beta_{1-28}$ on the evoked release of endogenous $A C h$ from hippocampal slices

\begin{tabular}{|c|c|c|c|c|c|}
\hline \multirow[b]{2}{*}{ Time (min) } & \multicolumn{5}{|c|}{ Concentrations of $A \beta_{1-2 \gamma}(\mathrm{M})$} \\
\hline & $10^{-16}$ & $10^{-14}$ & $10^{-12}$ & $10^{-111}$ & $10^{-8}$ \\
\hline $0-20$ & $110.8 \pm 10.5$ & $91.1 \pm 19.9$ & $76.9 \pm 19.1$ & $71.1 \pm 13.2$ & $63.9 \pm 20.1$ \\
\hline $20-40$ & $86.6 \pm 7.1$ & $77.6 \pm 17.7$ & $74.9 \pm 14.0$ & $69.9 \pm 11.9$ & $56.5 \pm 11.7^{* * *}$ \\
\hline $40-60$ & $82.4 \pm 14.3$ & $66.5 \pm 10.9^{*}$ & $60.1 \pm 17.0^{*}$ & $52.8 \pm 13.6^{*}$ & $49.7 \pm 15.7^{*}$ \\
\hline $0-60($ Total $)$ & $90.0 \pm 8.1$ & $77.9 \pm 12.3$ & $66.6 \pm 10.8^{*}$ & $62.9 \pm 9.2^{*}$ & $57.9 \pm 6.9^{* *}$ \\
\hline
\end{tabular}

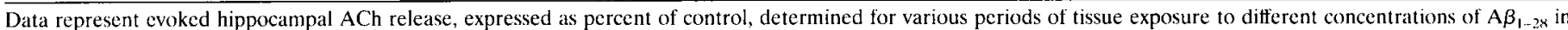
the presence of $25 \mathrm{~mm} \mathrm{KCl}$. The data for a given concentration represent mean $\pm \mathrm{SEM}$ of three experiments, each performed 5 times, ${ }^{*} p<0.05$; ${ }^{*} p<0.01$.

forebrain cholinergic neurons, provide a compelling anatomical substrate supporting a role for endogenous APP derivatives in the presynaptic regulation of $\mathrm{ACh}$ release in selected brain regions.

The underlying mechanism(s) associated with $A \beta$-induced inhibition of $A C h$ release is unknown. It was suggested initially that biological actions of $A \beta$-related peptides, which exhibit some sequence homology with substance $P$, may involve tachykinin (Yankner et al., 1990) or serpin-enzyme complex-related receptors (Joslin et al., 1991). However, this hypothesis has been challenged recently by several studies that failed to observe any interactions between these two systems, thus indicating that $\mathrm{A} \beta$ derivatives likely act via other pathways (Mitsuhashi et al., 1991; Pike et al., 1993). Moreover, $A \beta_{1-28}$ was shown here to inhibit ACh release potently while having no sequence homology with substance $P$. It is unlikely, therefore, that tachykinin receptors are involved in mediating the observed response.

Plasma membrane-associated APP exhibits a receptor-like architecture, and a region of its cytoplasmic domain is capable of complexing with GTP-binding proteins (Nishimoto et al., 1993). Using a monoclonal antibody against the extracellular domain of APP, it was shown recently that APP can act as a functional $\mathrm{G}_{\mathrm{o}}$-coupled receptor (Okamoto et al., 1995). These results, together with findings that $A \beta$ peptides can bind avidly to the $N$ terminus of the APP molecule, suggest that homologous binding may be involved in targeting biological responses of $A \beta$-related peptides (Strittmatter et al., 1993) such as the one observed in the present study. Alternatively, given the evidence of undisplaceable A $\beta$-binding profile to normal tissue (Maggio et al., 1992) and its ability to interact with cell membranes (Chauhan et al., 1993), it is possible that $A \beta$-related peptides might act either via an as yet undefined association to alter membrane permeability or via the activity of some associated proteins. In that regard, it is of interest to note that soluble $A \beta$ induces a dysfunction of $\mathrm{K}^{+}$channels in normal fibroblasts (Etcheberrigaray et al., 1993), which is a finding similar to those obtained in fibroblast and olfactory neuroblast studies of AD patients (Etcheberrigaray et al., 1994). In keeping with the purported role of $\mathrm{K}^{+}$channels in the acquisition of memory (Roberts, 1986; Hille, 1992), it has been shown that $A \beta$ impairs post-training cognitive processing (Flood et al., 1991, 1994) and induces $\mathrm{AD}$-like depletion of $\mathrm{Cp} 20$, a potent $\mathrm{K}^{+}$ channel-regulating memory-associated GTP-binding protein, in control human fibroblasts (Kim et al., 1995). Because many $\mathrm{K}^{+}$ channels play a critical role in the regulation of various cellular responses, including the release of neurotransmitters (Roberts, 1986; Hille, 1992; Etcheberrigaray et al., 1994), it is possible that interference with $\mathrm{K}^{+}$channels may be associated with the modulatory effects of $\mathrm{A} \beta$-related peptides on $\mathrm{ACh}$ release. This possibility currently is under investigation in our laboratory.

The modulatory effect of $A \beta$ on $A C h$ release may be relevant to the well known impairments of cholinergic functions in AD. The selective inhibition of $\mathrm{ACh}$ release from cortical and hippocampal slices, but not in the striatum, suggests that only cholinergic target areas severely afflicted in AD (Price, 1986; Hohmann et al., 1988; Wurtman, 1992; Geula and Mesulam, 1994) are sensitive to the inhibitory action of $\mathrm{A} \beta$-related peptides. Pharmacological evidence already has suggested that differences in the functional organization of the cholinergic synapse are observed between striatal interneurons and long cortical and hippocampal projections. For example, the nature of the autoreceptor regulating $\mathrm{ACh}$ release likely is different in these two groups of cholinergic neurons (Quirion, 1993). These findings, together with in vitro toxicity data (Yankner et al., 1990; Mattson et al., 1993; Pike et al., 1993; Cotman and Pike, 1994), provide a mechanistic framework supporting the idea that the preferential vulnerability of basal forebrain neurons and their projections in $\mathrm{AD}$ relate, at least in part, to their sensitivity to $A \beta$-related peptides.

Much evidence suggests that the APP can be processed either (1) via a nonamyloidogenic pathway in which the $\mathrm{N}$-terminal portion of APP is released into the extracellular space, or (2) via an alternative pathway that generates $A \beta$-related peptides (Cordell, 1994; Nitsch and Growdon, 1994; Selkoe, 1994). Agonistinduced activation of muscarinic $m_{1}$ and $m_{3}$ receptor subtypes, which are known to be coupled to protein kinase C (PKC) transduction pathways, has been shown to increase the secretion of soluble APP derivatives and, concomitantly, to reduce the production of amyloidogenic A $\beta$ peptides (Buxbaum et al., 1992; Nitsch et al., 1992; Nitsch and Growdon, 1994). It also has been reported that the lesioning of basal forebrain cholinergic neurons or a transient blockade of their transmission elevates the ex vivo synthesis of APP in cerebral cortex (Wallace et al., 1993). An alteration in normal APP processing pathway also has been reported after the destruction of selected neuronal populations, including cholinergic neurons (Iverfeldt et al., 1993). Collectively, these results point to a "protective role" of the normal cholinergic innervation that ensures the nonamyloidogenic maturation of APP (Iverfeldt et al., 1993; Wallace et al., 1993; Nitsch and Growdon, 1994). However, A $\beta$-related peptides under physiological conditions may be involved in the regulation of $\mathrm{ACh}$ release, which suggests the existence of reciprocal control mechanisms between cholinergic and $A \beta$-related systems in hippocampal and cortical regions. It now remains to be established how the normal biological functions of $A \beta$-related peptides are being compromised in $\mathrm{AD}$, leading to neuronal degeneration and/or in vivo assembly of insoluble amyloid derivatives. One hypothesis is that the overproduction or malfunctioning of degradation/clearance mechanisms, as well as alterations of the local microenvironment, increases levels of $A \beta$, which subsequently inhibits cholinergic transmission and leads to further increments of the processing of APP via the amyloidogenic pathway (Wallace et al., 1993; Cordell, 1994; Nitsch and Growdon, 1994; Selkoe, 1994). Such a situation 

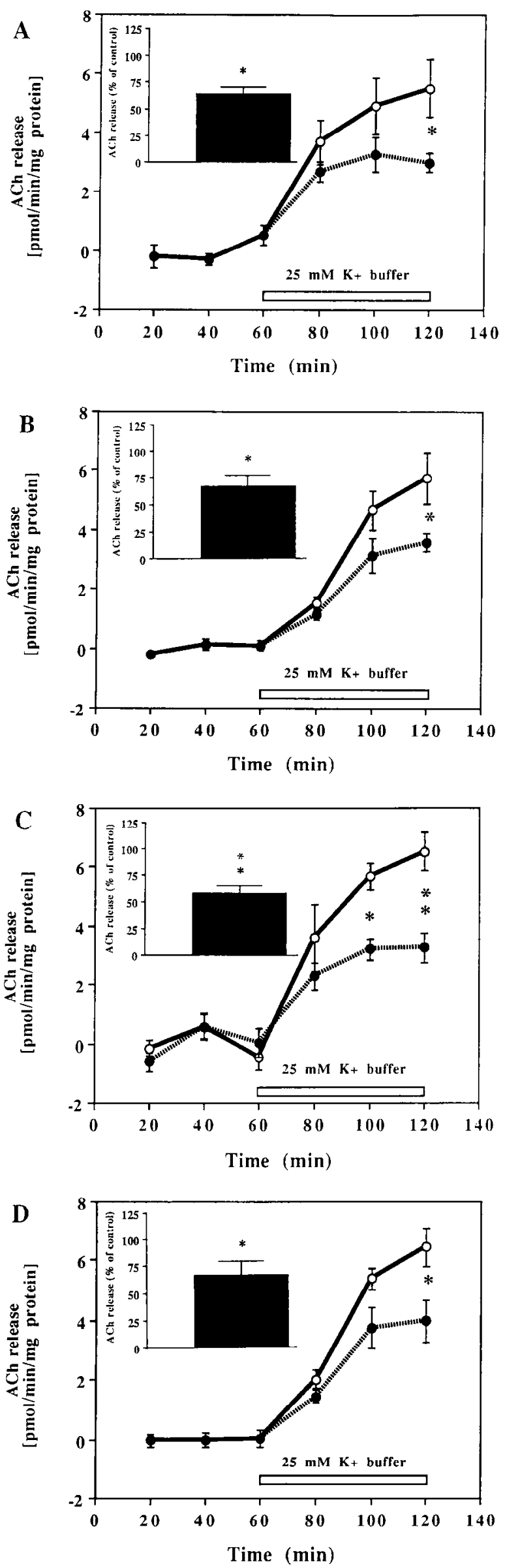

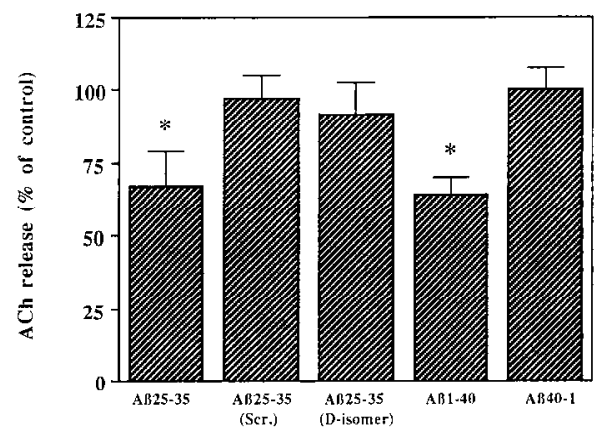

Figure 3. Comparative effects of $\mathrm{A} \beta_{25-35}$, scrambled (Scr.) $\mathrm{A} \beta_{25_{-35}}$, allD-isomer $A \beta_{25-35}, A \beta_{1-40}$, and reverse $A \beta_{1-40}$ (i.e., $A \beta_{40-1}$ ) on evoked hippocampal ACh release. Slices were depolarized with $25 \mathrm{~mm} \mathrm{~K}^{+}$buffer in the presence or absence (control) of $10^{-8} \mathrm{M}$ of each of these peptides. Unlike the regular peptides, endogenous $\mathrm{ACh}$ release was not altered significantly in the presence of any of the unnatural peptides. Data for each peptide are expressed as mean $\pm \operatorname{SEM}(n=10-15) .{ }^{*} p<0.05$.

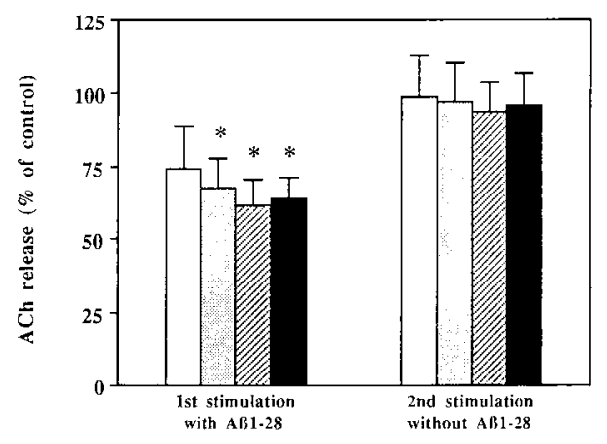

Figure 4. Evoked hippocampal $\mathrm{ACh}$ release after a pre-exposure of the tissue to $10^{-8} \mathrm{M} \mathrm{A} \beta_{1-28}$. Slices were stimulated with $25 \mathrm{mM} \mathrm{K}{ }^{+}$buffer for an initial period of $1 \mathrm{hr}$ in the presence or absence of $A \boldsymbol{\beta}_{1-28}$ peptide, rinsed for $40 \mathrm{~min}$, and stimulated for a second time for an additional $1 \mathrm{hr}$ without the peptide. Evoked release was inhibited in the first phase of stimulation but remained unaffected in the second period, demonstrating the lack of acute toxicity. Data are expressed as mean $\pm \operatorname{SEM}(n=12)$. ${ }^{*} p<0.05$. Open, 0-20 min; stippled, 20-40 min; hatched, 40-60 min; solid, total release.

would create a vicious cycle causing the gradual degeneration of neurons sensitive to $A \beta$-related peptides. Alternatively, at-risk cholinergic neurons may be affected first by undefined insults, leading to altered PKC inputs and the activation of the amyloidogenic pathway and, finally, cell death.

In summary, the present study shows that $\mathrm{A} \beta$-related peptides can inhibit $\mathrm{K}^{+}$-evoked $\mathrm{ACh}$ release potently in rat hippocampal and cortical slices. The effect is TTX-insensitive and involves a stereoselective interaction. Taken together, these results suggest that endogenous $\Lambda \beta$-related peptides act as potent inhibitors of $\mathrm{ACh}$ release and may serve as a basis for the functional interrelationship between $\mathrm{A} \beta$ toxicity and the vulnerability of some cholinergic neuronal populations in AD.

Figure 2. $A-D$, Comparative effects of various $\mathrm{A} \beta$-related peptides on evoked hippocampal ACh release. Slices were depolarized with $25 \mathrm{~mm}$ $\mathrm{K}^{+}$buffer in the presence (dotted line) or absence (solid line) of $10^{-8} \mathrm{M}$ $\mathrm{A} \beta_{1-42}(A), \mathrm{A} \beta_{1-40}(B), A \beta_{1-28}(C)$, or $\mathrm{A} \beta_{25-35}(D)$ peptide, respectively. Endogenous $A C h$ release was inhibited potently in the presence of each of these peptides during later periods of stimulation. The insets in $A-D$ represent total release as percentage of control for the respective peptide over $60 \mathrm{~min}$ of $\mathrm{KCl}$ stimulation. Data for each peptide are expressed as mean $\pm \operatorname{SEM}(n=10-15) .{ }^{*} p<0.05 ;{ }^{* *} p<0.01$. 


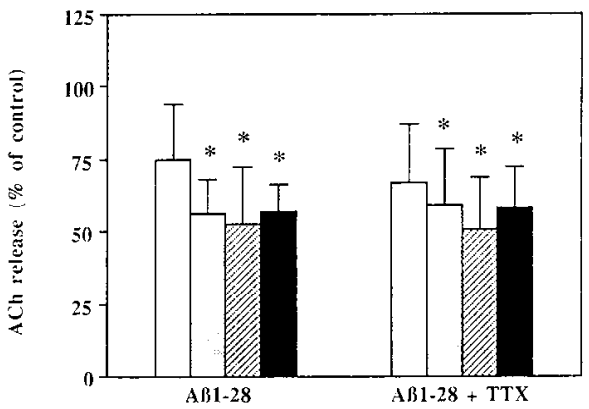

Figure 5. Effects of TTX on the $A \beta_{1-2 \gamma}$-induced inhibition of evoked ACh release from hippocampal slices. Tissue slices were depolarized with $25 \mathrm{mM} \mathrm{K}{ }^{+}$buffer in the presence or absence of $10^{8} \mathrm{M} \mathrm{A} \boldsymbol{\beta}_{1-28}$ alone or with the peptide and $10 \mu \mathrm{M}$ TTX. Evoked release was inhibited potently by the peptide with or without TTX. Data are expressed as mean \pm SEM $(n=12) .{ }^{*} p<0.05$. Open, 0-20 min; stippled, $20-40 \mathrm{~min}$; hatched, 40-60 min; solid, total release.
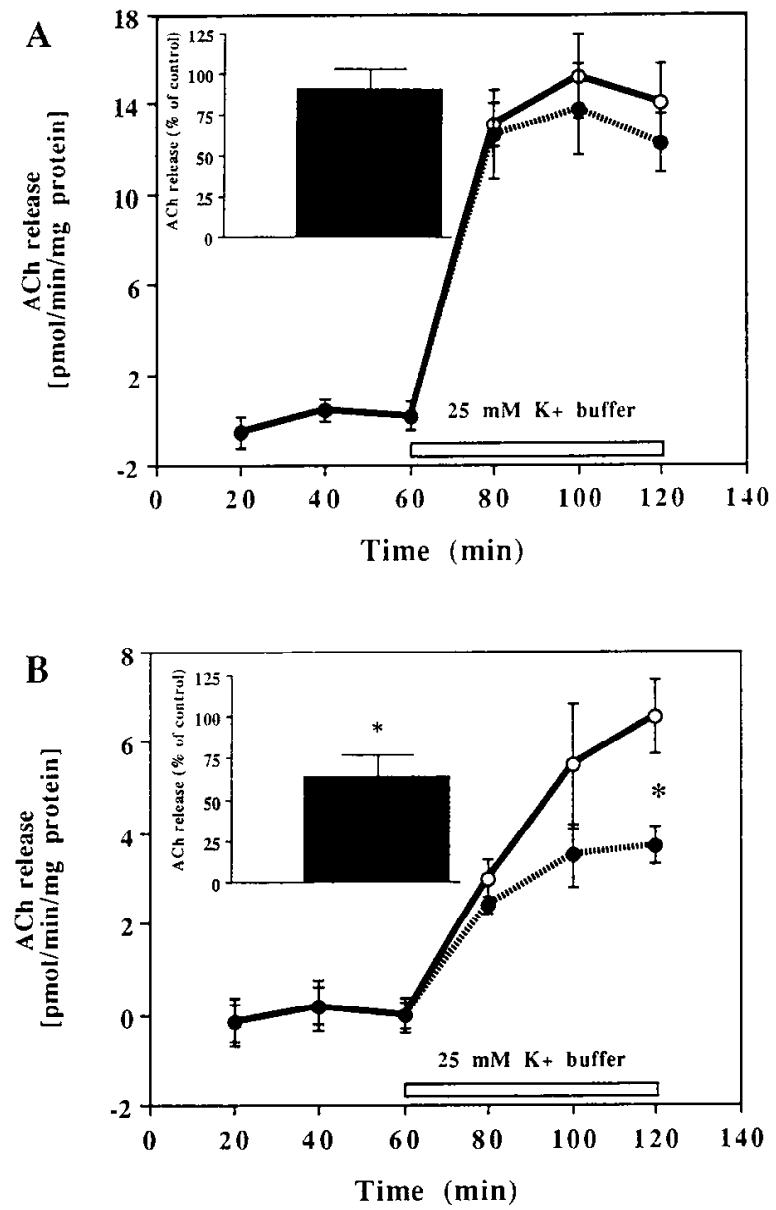

Figure 6. $A, B$, Time course effects of $\mathrm{A} \beta_{1-2 x}$ on the evoked $\mathrm{ACh}$ release from slices of the striatum $(A)$ and frontal cortex $(B)$. Tissue slices were stimulated with $25 \mathrm{mM} \mathrm{K}^{+}$buffer in the presence (dotted line) or absence (solid line) of $10^{8} \mathrm{M} \mathrm{A} \beta_{1-28}$. Evoked $\mathrm{ACh}$ release, although remaining unaffected in the striatum, was inhibited significantly in the frontal cortex in the presence of $A \beta_{1-28}$. The insets in $A$ and $B$ represent total release as percentage of control for the respective tissues over $60 \mathrm{~min}$ of $\mathrm{KCl}$ stimulation. Data are expressed as mean $\pm \operatorname{SEM}(n=10-12) .{ }^{*} p<0.05$.

\section{REFERENCES}

Abe F, Casamenti F, Giovannelli L, Scali C. Pepeu G (1994) Administration of amyloid $\beta$-peptides into the medial septum of rats decreases acetylcholine release from hippocampus in vivo. Brain Res 636:162-164.
Araujo DM, Lapchak PA, Collier B, Chabot J-G, Quirion R (1989) Insulin-like growth factor-I (somatomedin-C) receptors in the rat brain: distribution and interaction with the hippocampal cholinergic system. Brain Res 484:130-138.

Araujo DM, Lapchak PA, Collier B, Quirion R (1990) Evidence that somatostatin enhances endogenous acetylcholine release in the hippocampus. J Neurochem 55:1546-1555.

Beeson JG, Shelton ER, Chan HW, Gage FH (1994) Differential distribution of amyloid protein precursor immunoreactivity in the rat brain studied by using five different antibodies. J Comp Neurol 342:78-96.

Buxbaum JD, Oishi M, Chen HI, Pinkas-Kramarski R, Jaffe FA, Gandy SE, Greengard $P$ (1992) Cholinergic agonists and interleukin 1 regulate processing and secretion of the Alzheimer $\beta / \mathrm{A} 4$ amyloid protein precursor. Proc Natl Acad Sci USA 89:10075-10078.

Cai NS, Kiss B, Erdo SL (1991) Heterogeneity of $N$-methyl-D-aspartate receptors regulating the release of dopamine and acetylcholine from striatal slices. J Neurochem 57:2148-2151.

Chauhan A, Chauhan VPS, Brockerhoff H, Wisniewski HM (1993) Effect of amyloid beta-protein on membrane properties. In: Alzheimer's disease: advances in clinical and basic research (Corain $\mathrm{B}$, Iqbal $\mathrm{K}$, Nicolini M, Winblad B, Wisniewski H, Zatta P, eds), pp 431-439. London: Wiley-Interscience.

Cordell B (1994) $\beta$-Amyloid formation as a potential therapeutic target for Alzheimer's disease. Ann Rev Pharmacol Toxicol 34:69-89.

Colman CW, Pike CJ (1994) $\beta$-Amyloid and its contributions to neurodegeneration in Alzheimer disease. In: Alzheimer disease (Terry RD, Katzman R, Bick KL, eds), pp 305-315. New York: Raven.

Esch FS, Keim PS, Beattie EC, Blacher RW, Culwell AR, Oltersdorf T, McClure D, Ward PJ (1990) Cleavage of amyloid $\beta$ peptide during constitutive processing of its precursor. Science 248:1122-1124.

Etcheberrigaray R, Ito E, Kim CS, Alkon DL (1994) Soluble $\beta$-amyloid induction of Alzheimer's phenotype for human fibroblast $\mathrm{K}^{+}$channels. Science 264:276-278.

Etcheberrigaray R, Ito E, Oka K, Tofel-Grehl B, Gibson GE, Alkon DL (1993) Potassium channel dysfunction in fibroblasts identifics patients with Alzheimer's disease. Proc Natl Acad Sci USA 90:8209-8213.

Flood JF, Morley JE, Roberts E (1991) Amnestic effects in mice of four synthetic peptides homologous to amyloid $\beta$ protein from patients with Alzheimer disease. Proc Natl Acad Sci USA 88:3363-3366.

Flood JF, Morley JE, Roberts E (1994) An amyloid $\beta$-protein fragment, $\mathrm{A} \beta[12-28]$, equipotently impairs post-training memory processing when injected into different limbic system structures. Brain Res 663:271-276.

Frey P, Lis M, Ristig D, Stauss U, Amstutz R, Swoboda R, Staufenbiel M (1994) Studies on the mechanism of $\beta / \Lambda 4$ toxicity. Neurobiol $\Lambda$ ging [Suppl] 15:S18.

Games D, Adams D, Alessandrini R, Barbour R, Berthelette P, Blackwell C, Carr T, Clemens J, Donaldson T, Gillespie F, Guido T, Hagopian S, Johnson-Wood K, Khan K, Lee M, Leibowitz P, Lieberburg I, Little S, Masliah E, McConlogue L, Montoya-Zavala M, Mucke L, Paganini L, Penniman E, Power M, Schenk D, Seubert P, Snyder B, Soriano F, Tan H, Vitale J, Wadsworth S, Wolozin B, Zhao J (1995) Alzheimer type neuropathology in transgenic mice overexpressing V717F $\beta$-amyloid precursor protein. Nature 373:523-527.

Geula C, Mesulam MM (1994) Cholinergic systems and related neuropathological predilection patterns in Alzheimer's discasc. In: Alzheimer's disease (Terry RD, Katzman R, Bick KL, eds), pp 263-291. New York: Raven.

Giovannelli L, Casamenti F, Scali C, Bartolini L, Pepeu G (1995) Differential effects of amyloid peptides $\beta-(1-40)$ and $\beta-(25-35)$ injections into the rat nucleus basalis. Neuroscience 66:781-792.

Goldberg AM, McCaman RE (1973) The determination of picomole amounts of acetylcholine in mammalian brain. J Neurochem 20:1-8.

Haass C, Schlossmacher MG, Hung AY, Vigo-Pelfrey C, Mellon A, Ostaszewski BL, Lieberburg I, Koo EH, Schenk D, Teplow DB, Selkoe DJ (1992) Amyloid $\beta$-peptide is produced by cultured cells during normal metabolism. Nature 359:322-325.

Hanisch UK, Seto D, Quirion R (1993) Modulation of hippocampal acetylcholine release: a potent central action of intcrleukin-2. J Neurosci $13: 3368-3374$.

Hardy J, Allsop D (1991) Amyloid deposition as the central event in the aetiology of Alzheimer's disease. Trends Pharmacol Sci 12:383-388.

Hille B (1992) Ionic channels of excitable membranes, 2nd Ed. Sunderland, MA: Sinauer. 
Hohmann C, Antuono P, Coyle JT (1988) Basal forebrain cholinergic neurones and Alzheimer's disease. In: Handbook of psychopharmacology: psychopharmacology of the aging nervous system (Iversen LL, Snyder SH, eds), pp 69-106. New York: Plenum.

Iverfeldt K, Walaas SI, Greengard P (1993) Altered processing of Alzheimer amyloid precursor protein in response to neuronal degeneration. Proc Natl Acad Sci USA 90:4146-4150.

Joslin G, Krause JE, Hershey AD, Adams SP, Fallon RJ, Perlmutter DH (1991) Amyloid- $\beta$ peptide, substance $P$, and bombesin bind to the serpin-enzyme complex receptor. J Biol Chem 266:21897-21902.

Kang J, Lemaire H-G, Unterbeck A, Salbaum JM, Masters CL, Grzeschik K-H, Multhaup G, Beyreuther K, Muller-Hill B (1987) The precursor of Alzheimer's disease amyloid A4 protein resembles a cell surface receptor. Nature 325:733-736.

Kim CS, Han YF, Etcheberrigaray R, Nelson TJ, Olds JL, Yoshioka T, Alkon DL (1995) Alzheimer and $\beta$-amyloid treated fibroblasts demonstrate a decrease in a memory-associated GTP-binding protein, $\mathrm{Cp} 20$. Proc Natl Acad Sci USA 92:3060-3064.

LaFerla FM, Tinkle BT, Bieberich CJ, Haudenschild CC, Gilbert J (1995) The Alzheimer $A \beta$ peptide induces neurodegeneration and apoptic cell death in transgenic mice. Nature Genetics 9:21-30.

Lowry OH, Rosebrough NJ, Farr AL, Randall RJ (1952) Protein measurement with the Folin phenol reagent. J Biol Chem 193:265-275.

Maggio JE, Stimson ER, Ghilardi JR, Allen CJ, Dahl CE, Whitcomb DC, Vigna SR, Vinters HV, Labenski ME, Mantyh PW (1992) Reversible in vitro growth of Alzheimer's disease $\beta$-amyloid plaques by deposition of labeled amyloid peptide. Proc Natl Acad Sci USA 89:5462-5466.

Mattson MP, Barger SW, Cheng B, Licberburg I, Smith-Swintosky VL, Rydel RE (1993) $\beta$-Amyloid precursor protein metabolites and loss of neuronal $\mathrm{Ca}^{2+}$ homeostasis in Alzheimer's disease. Trends Neurosci 16:409-414.

Mitsuhashi M, Akitaya T, Turk CW, Payan DG (1991) Amyloid $\beta$ protein substituent peptides do not interact with the substance $P$ receptor expressed in cultured cells. Mol Brain Res 11:177-180.

Mullan M, Crawford F (1993) Genetic and molecular advances in Alzheimer's disease. Trends Neurosci 16:398-403.

Narahashi $T$ (1974) Chemicals as tools in the study of excitable membranes. Physiol Rev 54:813-889.

Nishimoto I, Okamoto T, Matsuura Y, Takahashi S, Okamoto T, Murayama $Y$, Ogata $E$ (1993) Alzheimer amyloid protein precursor complexes with brain GTP-binding protein Go. Nature 362:75-79.

Nitsch RM, Growdon JII (1994) Role of neurotransmission in the rcgulation of amyloid $\beta$-protein precursor processing. Biochem Pharmacol 47:1275-1284.

Nitsch RM, Slack BE, Wurtman RJ, Growdon JH (1992) Release of Alzheimer amyloid precursor derivatives stimulated by activation of muscarinic acetylcholine receptors. Science 258:304-307.

Okamoto T, Takeda S, Murayama Y, Ogata E, Nishimoto I (1995) Ligand-dependent $G$ protein coupling function of amyloid transmembrane precursor. J Biol Chem 270:4205-4208.
Ouimet CC, Baerwald KD, Gandy SE, Greengard P (1994) Immunocytochemical localization of amyloid precursor protein in the rat brain. $J$ Comp Neurol 348:244-260.

Pearce LB, Buck T, Adamec E (1991) Rapid kinetics of potassiumevoked release of acetylcholine from rat brain synaptosomes: analysis by rapid superfusion. J Neurochem 57:636-647.

Pike CJ, Burdick D, Walencewicz AJ, Glabe CG, Cotman CW (1993) Neurodegeneration induced by $\beta$-amyloid peptides in vitro: the role of peptide assembly state. J Neurosci 13:1676-1687.

Price D (1986) New perspectives on Alzheimer's disease. Annu Rev Neurosci $9: 489-512$.

Quirion R (1993) Cholinergic markers in Alzheimer's disease and the autoregulation of acetylcholine release. J Psychiatry Neurosci 18:226-234.

Roberts E (1986) Guides through the labyrinth of AD: dehydroepiandrosterone, potassium channels and the $\mathrm{C} 4$ component of complement. In: Treatment development strategies for Alzheimer's disease (Crook T, Bartus RT, Ferris S, Gershon S, eds), pp 173-219. New Haven, CT: Powley.

Rodriguez de lores Arnaiz G (1988) Molecular aspects of acetylcholine release: an overview. Prog Brain Res 98:213-218.

Selkoc D (1993) Physiological production of the $\beta$-amyloid protein and the mechanism of Alzheimer's disease. Trends Neurosci 16:403-409.

Selkoe D (1994) Normal and abnormal biology of the $\beta$-amyloid precursor protein. Annu Rev Neurosci 17:489-517.

Seubert P, Vigo-Pelfrey C, Esch F, Lee M, Dovey H, Davis D, Sinha S, Schlossmacher M, Whaley J, Swindlehurst C, McCormack R, Wolfert R, Selkoe D, Lieberburg I, Schenk D (1992) Isolation and quantification of soluble Alzheimer $\beta$-peptide from biological fluids. Nature 359:325-327.

Shoji M, Golde TE, Ghiso J, Cheung TT, Estus S, Shaffer LM, Cai XD, Makay DM, Tintner R, Frangione B, Younkin SG (1992) Production of Alzheimer $\beta$ protein by normal proteolytic processing. Science 258:126-129.

Sisodia SS, Koo EH, Beyreuther K, Unterbeck A, Price DL (1990) Evidence that $\beta$-amyloid protein in Alzheimer's disease is not derived by normal processing. Science 248:492-495.

St George-Hyslop P (1994) The molecular genetics of Alzheimer's disease. In: Alzheimer's disease (Terry RD, Katzman R, Bick KL, eds), pp 345-352. New York: Raven.

Strittmatter WJ, Huang DY, Bhasin R, Roses AD, Goldgaber D (1993) Avid binding of $\beta$ amyloid peptide to its own precursor. Exp Neurol 122:327-334.

Wallace W, Ahlcrs ST, Gotlib J, Bragin V, Sugar J, Gluck R, Shca PA, Davis KL, Haroutunian V (1993) Amyloid precursor protein in the cerebral cortex is rapidly and persistently induced by loss of subcortical innervation. Proc Natl Acad Sci USA 90:8712-8716.

Wurtman RJ (1992) Choline metabolism as a basis for the selective vulnerability of cholinergic neurones. Trends Neurosci 15:117-122.

Yankner BA, Duffy LK, Kirschner DA (1990) Neurotrophic and neurotoxic effects of amyloid $\beta$ protein: reversal by tachykinin neuropeptides. Science 250:279-282. 